\title{
Impact of urban parameterization on high resolution air quality forecast with the GEM - AQ model
}

\author{
J. Struzewska ${ }^{1}$ and J. W. Kaminski ${ }^{2,3,4}$ \\ ${ }^{1}$ Department of Environmental Engineering Systems, Warsaw University of Technology, Warsaw, Poland \\ ${ }^{2}$ WxPrime Corporation, Toronto, Ontario, Canada \\ ${ }^{3}$ Centre for Research in Earth and Space Science, York University, Toronto, Ontario, Canada \\ ${ }^{4}$ EcoForecast Foundation, Warsaw, Poland
}

Correspondence to: J. Struzewska (joanna.struzewska@is.pw.edu.pl)

Received: 30 December 2011 - Published in Atmos. Chem. Phys. Discuss.: 12 April 2012

Revised: 7 October 2012 - Accepted: 16 October 2012 - Published: 7 November 2012

\begin{abstract}
The aim of this study is to assess the impact of urban cover on high-resolution air quality forecast simulations with the GEM-AQ (Global Environmental Multiscale and Air Quality) model. The impact of urban area on the ambient atmosphere is non-stationary, and short-term variability of meteorological conditions may result in significant changes of the observed intensity of urban heat island and pollutant concentrations. In this study we used the Town Energy Balance (TEB) parameterization to represent urban effects on modelled meteorological and air quality parameters at the final nesting level with horizontal resolution of $\sim 5 \mathrm{~km}$ over Southern Poland. Three one-day cases representing different meteorological conditions were selected and the model was run with and without the TEB parameterization. Three urban cover categories were used in the TEB parameterization: mid-high buildings, very low buildings and low density suburbs. Urban cover layers were constructed based on an area fraction of towns in a grid cell. To analyze the impact of urban parameterization on modelled meteorological and air quality parameters, anomalies in the lowest model layer for the air temperature, wind speed and pollutant concentrations were calculated. Anomalies of the specific humidity fields indicate that the use of the TEB parameterization leads to a systematic reduction of moisture content in the air. Comparison with temperature and wind speed measurements taken at urban background monitoring stations shows that application of urban parameterization improves model results. For primary pollutants the impact of urban areas is most significant in regions characterized with high emissions. In most cases the anomalies of $\mathrm{NO}_{2}$ and $\mathrm{CO}$ concentrations were negative.
\end{abstract}

This reduction is most likely caused by an enhanced vertical mixing due to elevated surface temperature and modified vertical stability.

\section{Introduction}

The impact of urban environment on meteorological processes is a well-known phenomenon (e.g. Oke 1981; Lee, 1981; Oke, 1987; Eliasson and Holmer, 1990; HaegerEugensson and Holmer, 1999). A general concept describing differences in atmospheric structure between urban and rural areas was formulated based on several measurements studies over different cities (e.g., Bornstein, 1968; Bornstein and Azie, 1981; Draxler, 1986; King and Russell, 1988; Saitoh et al., 1996; Shahgedanova et al., 1997). Modifications in the thermal and turbulent structure of the atmosphere above a city (and downwind) have a significant impact on pollutant concentration patterns in proximity to conurbations.

Air quality modelling studies show that concentrations of pollutants above a city are characterized by large gradients due to high spatial and temporal variability of emission sources as well as complex flow patterns (Kambezis et al., 1995; Martilli et al., 2003; Sarrata et al., 2006; Menut et al., 2000; Cros et al., 2004). In addition, advective transport of pollutants emitted over a city can impact suburban areas.

Comprehensive representation of urban process in meteorological and air quality models is an active area of research (Fisher et al., 2005; Baklanov, 2006; Baklanov et al., 2010). Although results from a 1-D model of energy balance over 
(a)

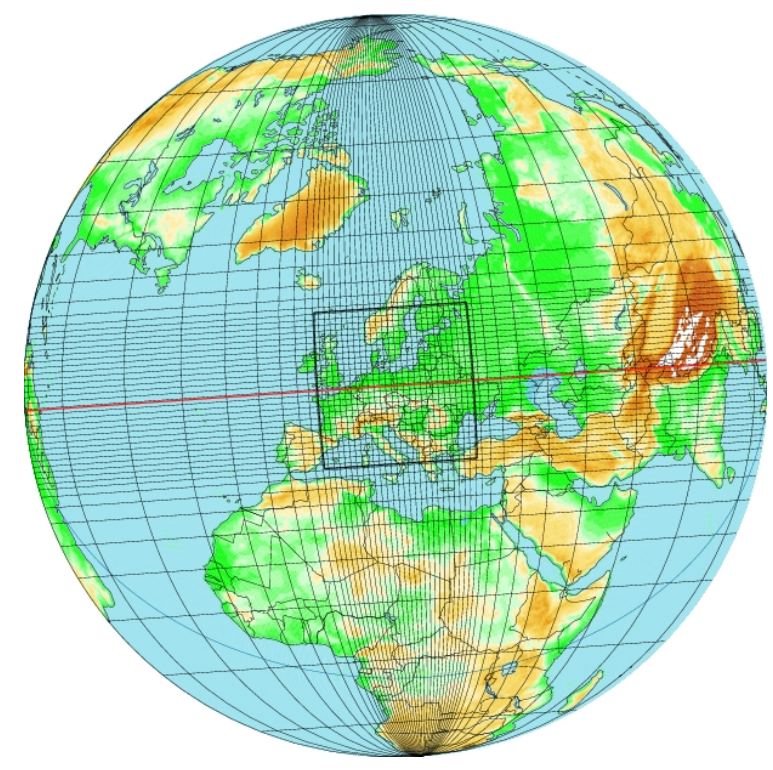

(b)

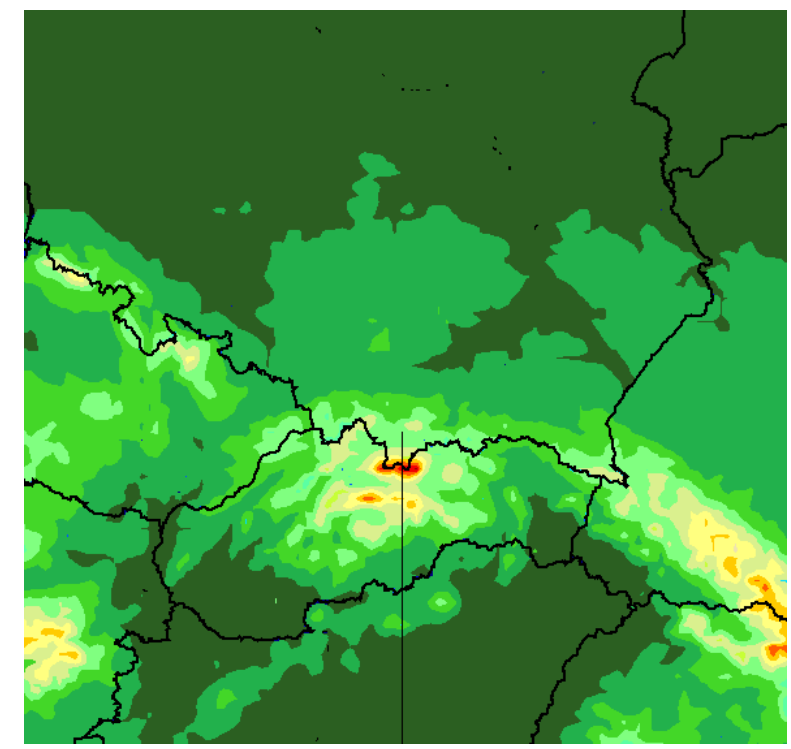

Fig. 1. GEM-AQ grid setup for EcoForecast.EU: (a) global variable grid $-0.22^{\circ}$ over Europe; (b) nested LAM grid $0.0625^{\circ}$.

a city show very good agreements with observations, implementations and applications of these processes in complex 3-D operational models are still challenging (e.g. Hamdi and Schayes, 2007; Baklanov et al., 2008; Oleson et al., 2008).

In the case of simulations with grid resolution of a few kilometres, urban structures become grid-scale features, which leads to the need for more accurate description of these processes. However, the applicability of many physical parameterizations is questionable at that resolution, and increasing complexity of parameterizations leads to additional uncertainties. In addition, the lack of high resolution emission inventories, difficulties with proper estimation of anthropogenic heat fluxes, and an insufficient number of representative measurements for model evaluation can introduce significant discrepancies between modelling results and observations.

The aim of this study is to assess the impact of urban land cover on high-resolution short-term meteorological and air quality forecasts calculated with the GEM-AQ model (www.EcoForecast.eu). The presented work is a pilot study for the GEM-AQ model and combines the sensitivity analysis with the evaluation aspect. The focus is on the changes in meteorological and air quality parameters due to urban effects for different large scale meteorological forcings that are representative for the Central European meteorological conditions.

\section{EcoForecast.eu air quality forecasting system}

The forecasting system is based on the GEM-AQ model (Kaminski et al., 2008). GEM-AQ is a numerical weather prediction model where air quality processes (gas phase and aerosols) are implemented on-line in the host meteorological model, the Global Environmental Multiscale (GEM) model, developed at Environment Canada (Côté et al., 1998).

The GEM-AQ model starts every $24 \mathrm{~h}$ from analysed meteorological fields prepared using the 4D-Var system (Gauthier et al., 2007). Model integration is done on a global variable resolution grid with a total of 200 by 182 grid points. The core part of the grid has 110 by 110 grid points and covers Europe with the uniform resolution of $25 \mathrm{~km}(0.22 \mathrm{deg})$ (Fig. 1a). In the vertical there are 28 hybrid levels with model top at $10 \mathrm{hPa}$. The forecast length is $78 \mathrm{~h}$ (starting 18:00 UTC the day before, allowing for a $6 \mathrm{~h}$ spin-up) with a time step of $600 \mathrm{~s}$. For the self-nested high resolution simulation a limited area model is used. Boundary conditions are provided every hour. A limited area high-resolution forecast is calculated on a 100 by 100 grid with a resolution of $0.0625 \mathrm{deg}$ with the rotated computational equator (Fig. 1b). The forecast is calculated for $75 \mathrm{~h}$ (starting 21:00 UTC the day before, with a $3 \mathrm{~h}$ spin-up period, starting from the third hour of the regional forecast) with a time step of $120 \mathrm{~s}$. The operational evaluation of the EcoForecast system is done on an annual basis against measurements from rural background and suburban stations (Struzewska at al., 2012; Struzewska and Kaminski, 2010, 2011; Kaminski and Struzewska, 2011).

As the presented work is a first stage of testing of the potential applicability of the urban parameterization in the 
operational high-resolution air quality forecast, the configuration setup and boundary conditions are exactly the same as in operational configuration. The urban parameterization module (TEB) was active in the final nesting stage only. The TEB module was run on-line in an interactive mode, where it contributed to the energy balance of the host meteorological model.

\section{Scenario setup with the TEB parameterization}

In the operational high resolution air quality forecast (EcoForecast.eu) with the GEM-AQ model over Europe/Poland, urban centres are represented in terms of enhanced emission fluxes only. As the host meteorological model treats the urban area as one of the land-use categories taken into account, the aerodynamic effects near surface were also included.

Urban effects in the GEM model are described with the TEB (Town Energy Balance) parameterization (Masson, 2000; Lemonsu et al., 2009). The GEM model with the TEB parameterisation was tested for Oklahoma City (USA) with the resolution of $300 \mathrm{~m}$ against the dataset from the Joint Urban 2003 field experiment (Lemonsu et al., 2009). Also, the TEB parameterisation was tested for Montreal Urban Snow Experiment (MUSE) 2005, but as an off-line urban model (Lemonsu et al., 2010).

The TEB scheme describes a city as an ensemble of idealized urban canyons formed of roofs, walls and streets. Separate surface energy budgets are solved for each of these three different canyon surfaces. TEB takes into account the 3-D geometry of urban surfaces for radiative trapping and shadow effects, heat storage, mean wind, temperature and humidity inside street canyons, and water and snow on roofs and streets. Additional assumptions are the isotropy of the street orientations and no crossing streets.

The TEB parameterization accounts for twelve categories of urban morphology. Some of the parameters proposed by Lemonsu (2009) for the GEM model for each urban land-use class are summarized in Table 1. The built-up fraction defines the impact of all other parameters, as it is used as a weighting factor. The default building height and the anthropogenic heat flux show largest differences between particular urban cover types.

The resolution of the computational grid $\left(0.0625^{\circ}\right)$ used in this study is relatively coarse in terms of urban morphology representation. The city is represented very roughly and an "average city cover" in a grid square is not representative for specific streets and buildings located within the grid square. Moreover, the nested domain covers a region of approximately $800 \times 800 \mathrm{~km}$ and the detailed analysis for all cities in the domain would be difficult. The urban land-cover was represented in a simplified way. It was assumed that at the model resolution any urban area can be represented with only three mutually exclusive urban cover categories - city centre, middle suburbs and outer suburbs.
To select the TEB land cover categories that best represent the features of major cities within the domain, a qualitative analysis of their built-up structure was done. The information below was obtained from the Spatial Planning Offices in different cities:

- In Warsaw $\left(500 \mathrm{~km}^{2}\right)$ there are different types of buildings, including single houses and skyscrapers. In the city centre there are $\sim 40$ buildings higher than $65 \mathrm{~m}$. Dominant building height is $20 \mathrm{~m}$ on average (ranging from 15 to $30 \mathrm{~m}$ in different suburbs);

- In Lodz $\left(300 \mathrm{~km}^{2}\right)$ the dense built-up areas dominate. The average height of buildings is $\sim 15-30 \mathrm{~m}$;

- Average built-up height in Krakow $\left(327 \mathrm{~km}^{2}\right)$ is in the range of $15-30 \mathrm{~m}$. In the city centre the buildings are lower ( $2-3$ stories), with a height of $10 \mathrm{~m}$. Buildings in surrounding suburbs are higher $(15-30 \mathrm{~m})$;

- In Katowice $\left(165 \mathrm{~km}^{2}\right)$ the average building height is $10-15 \mathrm{~m}$. In the city centre and surrounding suburbs there are single buildings as high as $70 \mathrm{~m}$; however, most dominant are sparse buildings;

- Wroclaw $\left(293 \mathrm{~km}^{2}\right)$ built-up area is dominated by 3-4 storey buildings, with the average height of $15-30 \mathrm{~m}$;

- The centre of Poznan $\left(262 \mathrm{~km}^{2}\right)$ is characterized by 3-5 storey houses and single high buildings $(70-80 \mathrm{~m})$. The average height of the buildings in surrounding suburbs is $15-30 \mathrm{~m}$.

The information above allows us to assume that, on average, the city centres can be represented with the TEB class "mid-high buildings", with the default average building height of $25 \mathrm{~m}$ and the built-up fraction of $90 \%$. The anthropogenic heat flux (taken as a sum of traffic and industrial sources) is $30 \mathrm{~W} \mathrm{~m}^{-2}$. However, the value of this parameter is most likely region dependent and it might be slightly underestimated in the current setup as compared to studies done for cities in Poland by Klysik (1996) and Bagienski (2006). For the representation of middle suburbs, a "very low buildings" TEB class, with the built-up fraction of $85 \%$, was used. This category is characterized by the same value of the anthropogenic heat release as "mid-high buildings", but average building height is lower and set at $8 \mathrm{~m}$. To describe outer suburbs, a "low-density suburbs" class was used. The average building height is $8 \mathrm{~m}$, but the built-up fraction is low (18\%) and the value of the anthropogenic heat flux is reduced by half $\left(15 \mathrm{~W} \mathrm{~m}^{-2}\right)$.

The standard geophysical data from the GEM model was used to define three layers described above as input data for the TEB parameterization. Land cover in the GEM model is represented by twenty six classes, including water bodies, ice, and various kinds of soils and vegetation covers (Loveland et al., 2000). This dataset includes the urban class, 
Table 1. Urban land-use categories in TEB - default settings for selected parameters in the GEM model.

\begin{tabular}{llrrr|r}
\hline No. & TEB urban cover & $\begin{array}{r}\text { Built-up } \\
\text { fraction } \\
{[0-1]}\end{array}$ & $\begin{array}{r}\text { Average } \\
\text { building } \\
\text { height } \\
{[\mathrm{m}]}\end{array}$ & $\begin{array}{r}\text { Anthrop } \\
\text { heat } \\
\text { flux } \\
{\left[\mathrm{W} \mathrm{m}^{-2}\right]}\end{array}$ & GEM approach \\
\hline 1 & High buildings & 0.95 & 39 & 30 & \\
\hline 2 & Mid-high buildings & 0.90 & 25 & 30 & City center \\
\hline 3 & Low buildings & 0.90 & 13 & 30 & \\
\hline 4 & Very low buildings & 0.85 & 8 & 30 & Middle suburbs \\
\hline 5 & Industrial areas & 0.85 & 8 & 50 & \\
6 & Sparse buildings & 0.40 & 12 & 15 & \\
7 & Roads and parking areas & 0.98 & 5 & 30 & \\
8 & Road borders & 0.70 & 5 & 30 & \\
9 & High-density suburbs & 0.44 & 5 & 15 & \\
10 & Mid-density suburbs & 0.27 & 5 & 15 & \\
\hline 11 & Low-density suburbs & 0.18 & 8 & 15 & Outer suburbs \\
\hline 12 & Mix of built/nature & 0.25 & 8 & 0 & \\
\hline
\end{tabular}

which is defined as a fraction of built-up area in the grid cell (Fig. 2a). The value of "urban fraction" in a grid cell was used as base information. As the selected layers are assumed to be mutually exclusive, the thresholds were set to distinguish the three urban cover classes. The grid cells with an urban fraction greater than $35 \%$ were classified as "city centre" (Fig. 2b). The grid cells characterized with the urban fraction in the range $35 \%-5 \%$ were assumed to represent "middle suburbs" (Fig. 2c), and below $5 \%$, "outer suburbs" (Fig. 2d). This indicates that for most urban regions the anthropogenic heat flux was assumed to be $30 \mathrm{~W} \mathrm{~m}^{-2}$. The aerodynamic effects would be different in city centre and surrounding suburbs due to a significant difference between assumed average building heights. Major differences are related to the city centre, which should have the most significant impact.

\section{Analysis}

The impact of urban area on the ambient atmosphere changes with time over the domain, and short-term variability of meteorological conditions may result in significant variation of the observed intensity of urban heat island (UHI) (e.g. regional wind speed, cloudiness). In the operational setup the GEM-AQ model starts every $24 \mathrm{~h}$ from analysed meteorological fields. Objective analysis is prepared on a global grid with resolution $\sim 35 \mathrm{~km}$ using the 4D-Var system (Gauthier et al., 2007). Thus, fine scale meteorological characteristics that result from the TEB parameterization are not carried between simulations. As the purpose of the study is to assess the applicability of TEB in an operational air quality forecast, the focus is on the interpretation of the short term variability. The 'average situations' with a different temperature variability range representing autumn, winter and spring seasons were selected. Also, different weather patterns (strong wind/moderate wind) were investigated. The following three one-day cases give a good representation of circulation patterns over Central Europe for these seasons:

- 6 November 2010 (frontal passage),

- 3 January 2011 (low wind, clear sky conditions, cold air mass)

- 29 March 2011 (moderate wind and cloudiness).

For each case two model simulations were undertaken - a reference run without the TEB parameterization and urban scenario with TEB. To analyze the impact of urban parameterization on modelled meteorological and air quality parameters, anomalies in the lowest model layer for the temperature, wind speed and pollutant concentrations were calculated. The hour chosen for the interpretation and graphical presentation for each modelled case represents the largest impact of the TEB parameterisation on calculated temperature fields.

Model evaluation was done using measurements taken at selected urban background air quality monitoring stations. As the complex structure of city land cover may result in relatively large differences between observations taken at different locations in a given city, only stations measuring meteorological and air quality parameters were taken into account. The location and characteristics of the stations, as well as the list of measured parameters are given in Table 2 .

Modelled meteorological parameters and pollutant concentrations taken for the comparison represent the average value calculated for the lowest model layer. 
(a) GEM urban cover - fraction

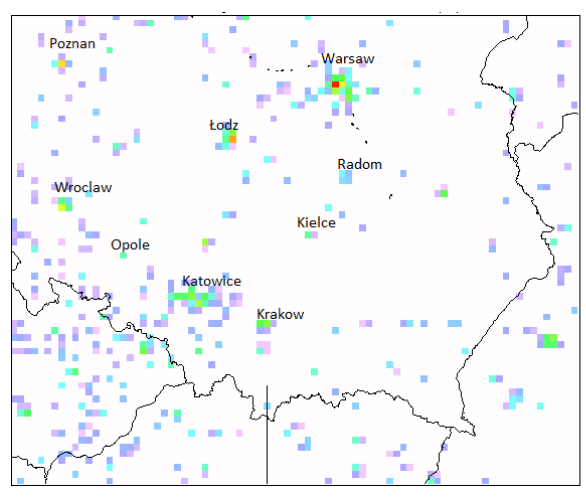

(c) Middle suburbs (very low buildings class)

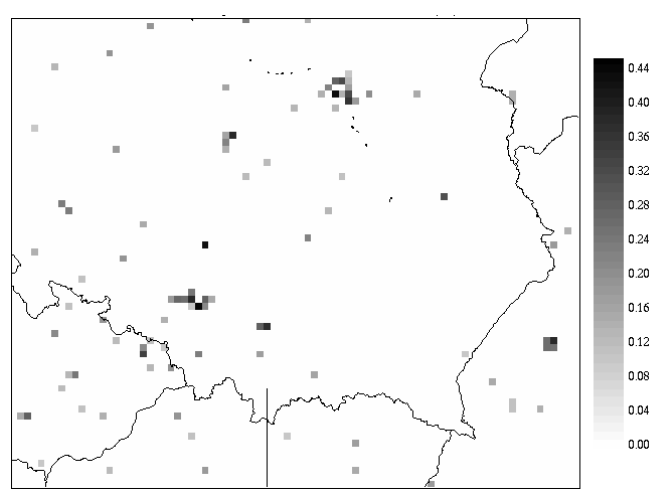

(b) City centre (mid-high buildings class)

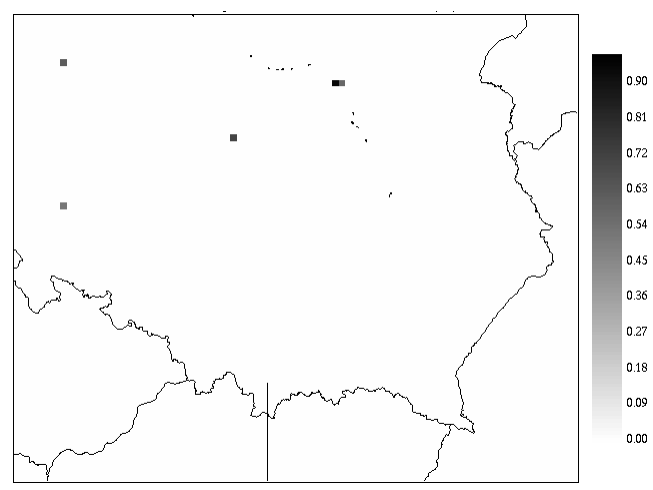

(d) Low-density suburbs

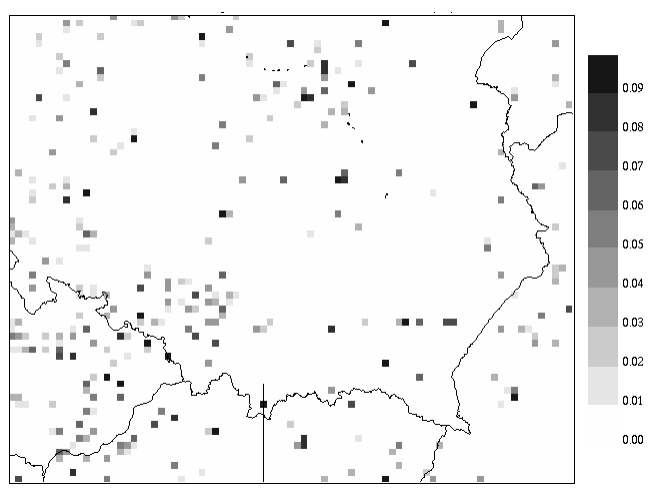

Fig. 2. Urban description - original dataset and input layers for TEB (a) urban fraction - default GEM input data generated from the GenGeo interface for the nested LAM grid; (b) "city centre"; (c) "middle suburbs"; (d) "outer suburbs".

Table 2. Location and characteristics of monitoring sites and parameters observed (usually the data were not available for all analysed days).

\begin{tabular}{|c|c|c|c|c|c|c|c|c|}
\hline \multirow[t]{2}{*}{ Station name } & \multirow[t]{2}{*}{ Lon } & \multirow[t]{2}{*}{ Lat } & \multicolumn{6}{|c|}{ Parameters } \\
\hline & & & $T$ & $U$ & RH & $\mathrm{NO}_{2}$ & $\mathrm{O}_{3}$ & $\mathrm{CO}$ \\
\hline Poznan-Polanka & 16.959 & 52.399 & $\mathrm{x}$ & $\mathrm{x}$ & $\mathrm{x}$ & $\mathrm{x}$ & & $\mathrm{x}$ \\
\hline Poznan-Botaniczny & 16.877 & 52.420 & $\mathrm{x}$ & $\mathrm{x}$ & $\mathrm{x}$ & $\mathrm{x}$ & & $\mathrm{x}$ \\
\hline Kielce & 20.605 & 50.872 & $\mathrm{x}$ & $\mathrm{x}$ & $\mathrm{x}$ & $\mathrm{x}$ & $\mathrm{x}$ & $\mathrm{x}$ \\
\hline Kedzierzyn -Kozle & 18.236 & 50.349 & $\mathrm{x}$ & $\mathrm{x}$ & $\mathrm{x}$ & $\mathrm{x}$ & $\mathrm{x}$ & $\mathrm{x}$ \\
\hline Opole & 17.924 & 50.666 & $\mathrm{x}$ & $\mathrm{x}$ & $\mathrm{x}$ & $\mathrm{x}$ & & \\
\hline Wroclaw-Korzeniowskiego & 17.029 & 51.129 & & $\mathrm{x}$ & & $\mathrm{x}$ & $\mathrm{x}$ & $\mathrm{x}$ \\
\hline Wroclaw-Bartnicza & 17.14 & 51.116 & $\mathrm{x}$ & $\mathrm{x}$ & $\mathrm{x}$ & $\mathrm{x}$ & $\mathrm{x}$ & \\
\hline Krakow-NowaHuta & 20.052 & 50.068 & $\mathrm{x}$ & & & $\mathrm{x}$ & & $\mathrm{x}$ \\
\hline Trzebinia & 19.473 & 50.161 & $\mathrm{x}$ & & & $\mathrm{x}$ & & $\mathrm{x}$ \\
\hline Warsaw-Krucza & 21.023 & 52.225 & $\mathrm{x}$ & $\mathrm{x}$ & $\mathrm{x}$ & $\mathrm{x}$ & $\mathrm{x}$ & $\mathrm{x}$ \\
\hline Warsaw-Al.Niepodleglosci & 21.006 & 52.219 & $\mathrm{x}$ & & & $\mathrm{x}$ & & $\mathrm{x}$ \\
\hline Warsaw-Targowek & 21.039 & 52.285 & $\mathrm{x}$ & $\mathrm{x}$ & & $\mathrm{x}$ & $\mathrm{x}$ & $\mathrm{x}$ \\
\hline Warsaw-Ursynow & 21.039 & 52.161 & $\mathrm{x}$ & $\mathrm{x}$ & $\mathrm{x}$ & $\mathrm{x}$ & $\mathrm{x}$ & \\
\hline
\end{tabular}




\subsection{November 2010}

\subsubsection{Meteorological situation}

On 6 November 2010 meteorological conditions over Central Europe were dynamically changing. A low pressure system located over Germany moved eastward. Frontal systems crossing the area of Poland caused an inflow from the southern direction in the morning (warm front) and the rapid change of wind direction associated with a cold front passage. The average wind speed was in the range of $3-5 \mathrm{~m} \mathrm{~s}^{-1}$. The sky was overcast with a wide zone of precipitation.

Measurements from the air quality monitoring sites showed rapid temperature decrease by approximately $5^{\circ} \mathrm{C}$ in the afternoon. At some stations (Kielce, Krakow-Nowa Huta and Trzebinia) there was also an increase of temperature during the afternoon due to the influence of the warm sector of the frontal system.

\subsubsection{Sensitivity study}

Analysis of the spatial pattern of the temperature anomalies (calculated as a difference between urban and non-urban scenarios) showed that the impact of the TEB parameterization on model results was small relative to non-urban simulation. A weak UHI developed in the morning over the largest cities, but during the daytime, due to relatively strong wind speed, the temperature differences between urban and rural sites were not significant (Fig. 3a). UHI effect appeared again at night after passage of two frontal systems. Analysis of the time series shows that UHI effect was observed in Poznan and Wroclaw during the evening and night (Mean Bias Error - MBE - averaged over stations is $0.37^{\circ} \mathrm{C}$ ). For a station in Warsaw there was small but systematic temperature increase in the TEB scenario (MBE averaged over stations is $0.29^{\circ} \mathrm{C}$ ). For other stations the urban effect was negligible.

Wind speed was lower over most urban areas by about $0.5-1 \mathrm{~m} \mathrm{~s}^{-1}$. Figure $3 \mathrm{~b}$ shows the wind speed anomalies at 15:00 UTC. The magnitude of the anomalies relate (were proportional) to the regional wind speed - at locations in western and southern parts of Poland the differences between urban and non-urban scenarios are most significant before the cold front passage and in general decrease over the simulation period. In Warsaw, the modelled wind speed rapidly increased in early afternoon. Time series analysis shows the opposite pattern for locations in Poznan and city center in Warsaw - the modelled wind speed is slightly greater for the urban scenario $\left(0.28 \mathrm{~m} \mathrm{~s}^{-1}\right)$.

Model simulation showed a decrease of water vapour content over the largest cities. Analysis of the time series showed that this tendency occurs at all 13 stations. The magnitude of the difference is closely related to the urban fraction of the land use class in the corresponding grid cell. Largest differences are noted at two stations in the centre of Warsaw $(\sim 11 \%)$ and in Poznan $(\sim 5 \%)$. For other stations the dif- ference between urban and non-urban scenarios varies in the range of $2-5 \%$. For Trzebinia there is no significant difference in the specific humidity field between scenarios.

Due to a strong advection, the spatial pattern of the anomalies for $\mathrm{NO}_{2}$ and $\mathrm{O}_{3}$ do not directly relate to the location of cities, although the largest differences occurred over Warsaw agglomeration. In general, $\mathrm{NO}_{2}$ concentrations are slightly lower for urban scenario (up to $5 \mathrm{ppb}_{v}$ ) and in consequence, over the same regions $\mathrm{O}_{3}$ concentration are slightly higher (Fig. 4).

Time series analysis confirms that in the case of an urban scenario, modelled $\mathrm{NO}_{2}$ concentrations are systematically lower, although the difference is small $-2 \mu \mathrm{g} \mathrm{m}^{-3}$ on average $\left(1-1.5 \mathrm{ppb}_{v}\right)$. For Poznan and Kedzierzyn-Kozle there was no difference in $\mathrm{NO}_{2}$ concentration between the two scenarios. As a result, $\mathrm{O}_{3}$ concentrations are higher in the simulation with urban parameterization. The differences are also small and in the range of $2-4 \mu \mathrm{g} \mathrm{m}^{-} 3\left(1-2 \mathrm{ppb}_{v}\right)$

\subsubsection{Model evaluation}

On 6 November 2010 meteorological measurements were available from 9 stations for air temperature, 6 stations for wind speed and 5 stations for relative humidity.

The observed air temperature decrease was reproduced in model simulations. In the western part of the domain modelled temperature was overestimated (Poznan, Opole, Wroclaw), while in Warsaw temperature for all sites was slightly underestimated (average MBE is $-2.3^{\circ} \mathrm{C}$ ). In grid cells corresponding to Kielce, Krakow-Nowa Huta and Trzebinia the agreement of modelled values with measurements was good, in spite of the fact that the warm front passage in the afternoon was not captured. The average difference between scenarios was smaller than differences between model and measurements. The model tends to overestimate the wind speed by about $1.5 \mathrm{~m} \mathrm{~s}^{-1}$. The best agreement was found for stations in Wroclaw $\left(\mathrm{MBE}=0.85 \mathrm{~m} \mathrm{~s}^{-1}\right)$. The temporal variability was reproduced correctly at most of the stations. Relative humidity observations at 2 stations were not calibrated and showed $98 \%$ over the day. For other locations the model reproduced well the temporal variability; however, there is no systematic bias, as for Kielce the model overestimated by about $8.5 \%$ while for Opole there was a systematic underestimation by $10.4 \%$. Figure 5 shows the time series for Kielce station for temperature, wind speed and relative humidity.

Measurements of air pollutant concentrations were available from 10 stations for $\mathrm{NO}_{2}, 6$ stations for $\mathrm{O}_{3}$ and 8 stations for $\mathrm{CO}$. Modelled $\mathrm{NO}_{2}$ concentrations show good agreement with the range of the observed $\mathrm{NO}_{2}$ levels on that day, although variability pattern related to emission fluxes was not reproduced (Fig. 6). The model underestimated concentrations for Poznan and for the traffic station Warsaw-Al. Niepodleglosci, which indicates the need to revise emission fluxes in urban areas. The modelled $\mathrm{O}_{3}$ levels show good agreement with observations in terms of daily average (non- 
(a) Temperature anomaly $\left[{ }^{\circ} \mathrm{C}\right]$

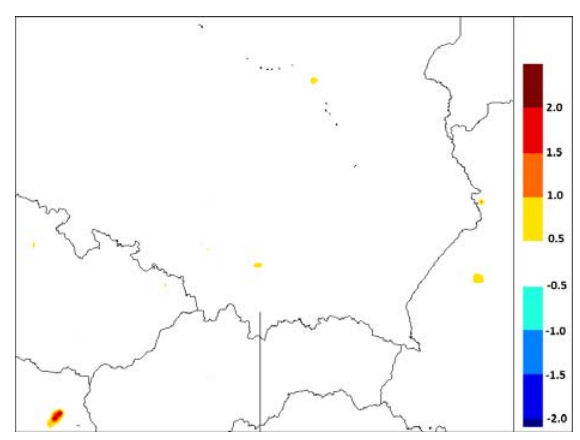

(b) Wind speed anomaly $[\mathrm{m} / \mathrm{s}]$

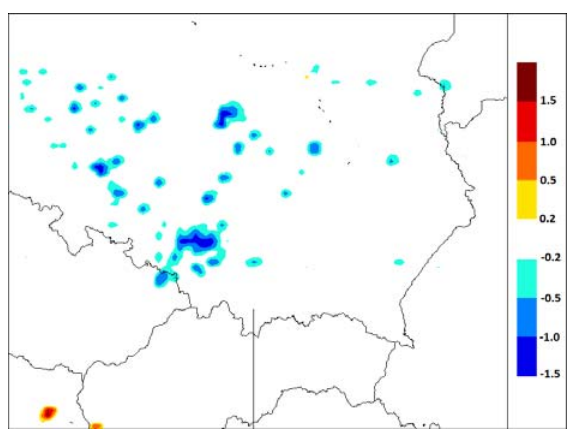

Fig. 3. Temperature (a) and wind speed (b) anomaly calculated as the difference between urban and non-urban scenarios - 6 November 2010 , 15:00 UTC.

(a) $\mathrm{NO}_{2}$ concentration anomaly $\left[\mathrm{ppb}_{\mathrm{v}}\right]$

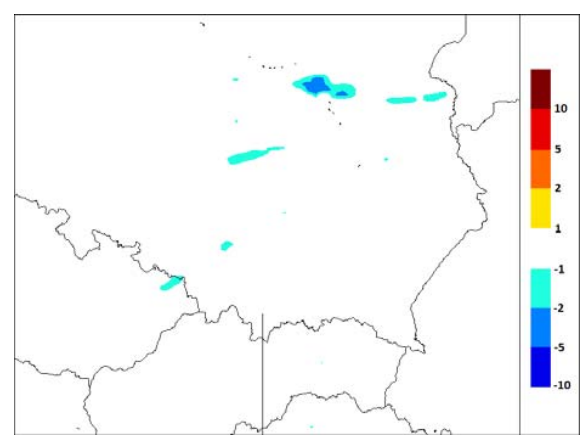

(b) $\mathrm{O}_{3}$ concentration anomaly $\left[\mathrm{ppb}_{\mathrm{v}}\right]$

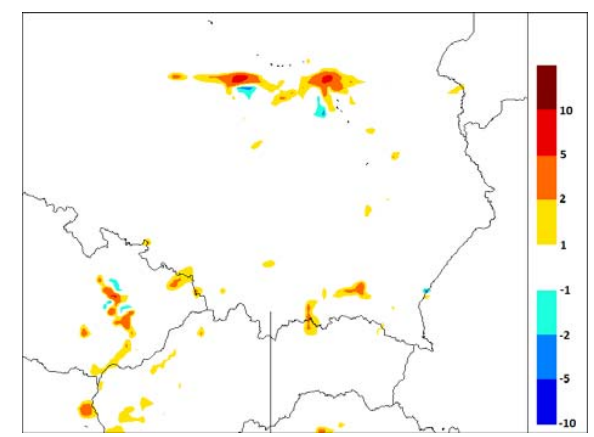

Fig. 4. $\mathrm{NO}_{2}$ (a) and $\mathrm{O}_{3}$ (b) concentration anomalies calculated as a difference between urban and non-urban scenarios in the lowest model layer - 6 November 2010, 15:00 UTC.

urban $\mathrm{MBE}=2.2 \mu \mathrm{g} \mathrm{m}^{-3}$, urban $\mathrm{MBE}=5.2 \mu \mathrm{g} \mathrm{m}^{-3}$ ). However, diurnal variability was not reproduced.

\subsection{January 2011}

\subsubsection{Meteorological situation}

On 3 January 2011 the meteorological situation over Central Europe was influenced by a high pressure system centred over France. In Poland, the prevailing wind speed from western directions was low. Light and moderate cloud cover over Poland favoured temperature decrease from $-5^{\circ} \mathrm{C}$ during the day to $-10^{\circ} \mathrm{C}$ at night in the regions with clear sky conditions.

\subsubsection{Sensitivity study}

The impact of urban areas is significant and spatial pattern of anomalies for meteorological and air quality parameters is closely related to the location of the urban mask. Temperature anomalies are positive over most of the cities in the domain, and the temperature differences between rural and urban areas increased over the day by up to $5-6^{\circ} \mathrm{C}$. Tem- perature difference at 12:00 UTC is shown in Fig. 7a. The regions with the negative anomalies are also present, but this effect was non-systematic and relatively small.

Analysis of the time series shows that there is a systematic tendency to increase modelled temperature in the city for the urban scenario. The difference between the two scenarios is the largest at the grid cell corresponding to the station in Poznan. At the rest of the sites the temperature anomaly is smaller, but positive $\left(\mathrm{MBE}=0.4-1.6^{\circ} \mathrm{C}\right)$.

Analysis of the spatial pattern of wind anomalies shows that wind speed reduction over city areas is on average from 1 to $1.5 \mathrm{~m} \mathrm{~s}^{-1}$. In contrast to the 6 November 2010 case, where the magnitude of anomalies was proportional to the large scale wind speed, the largest differences are over the areas with the biggest built-up fraction of the land use in a grid cell (Fig. 7b).

Analysis of time series shows that in Warsaw and Poznan the wind anomaly is quasi-constant during the day, while in other cities it is changing in time. At Trzebinia station there is no difference between urban and non-urban scenarios. As on 6 November, for the grid cells in Poznan and two stations in Warsaw centre, the opposite effect is seen and the wind speed 

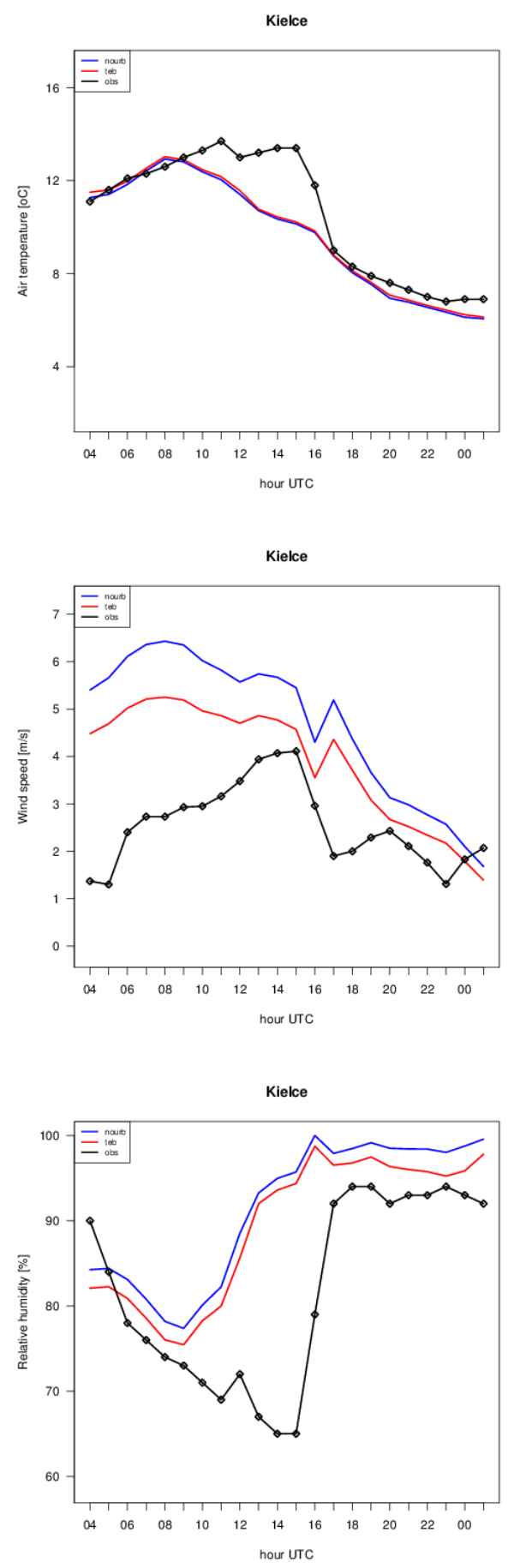

Fig. 5. Comparison of modelled meteorological parameters with observations from Kielce station for 6 November 2010 (red line urban scenario, blue line - non-urban scenario, black line - observations).

increases for the urban scenario as compared to the reference run.

The pattern of specific humidity anomalies is very complex. Positive and negative differences in the range of
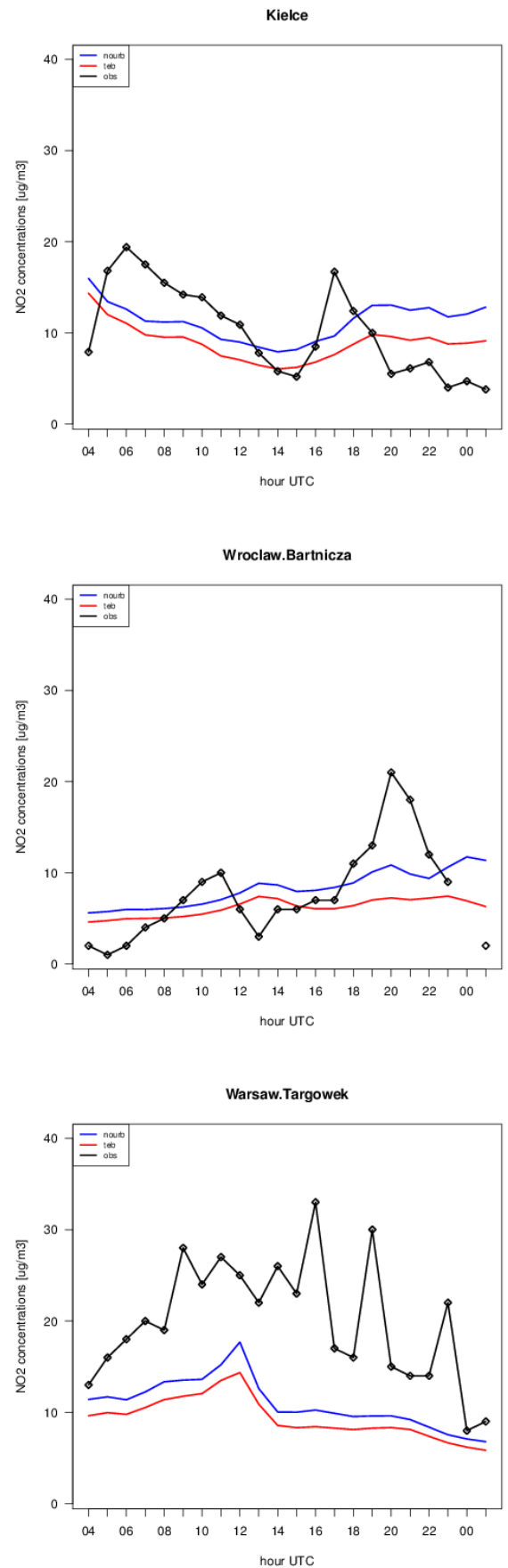

Fig. 6. Comparison of modelled $\mathrm{NO}_{2}$ concentrations with observations from station Kielce, Wroclaw-Bartnicza, Warsaw-Targowek for 6 November 2010 (red line - urban scenario, blue line - nonurban scenario, black line - observations).

$\pm 0.5 \mathrm{~g} \mathrm{~kg}^{-1}$ were present not only over the cities but also over the entire domain.

For most locations the results obtained for the relative humidity in urban scenario were lower as compared to the reference scenario, on average by $5 \%$. The differences are larger 
(a) Temperature anomaly $\left[{ }^{\circ} \mathrm{C}\right]$

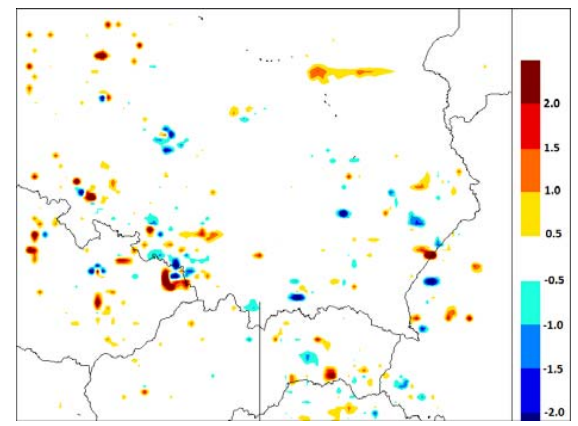

(b) Wind speed anomaly $[\mathrm{m} / \mathrm{s}]$

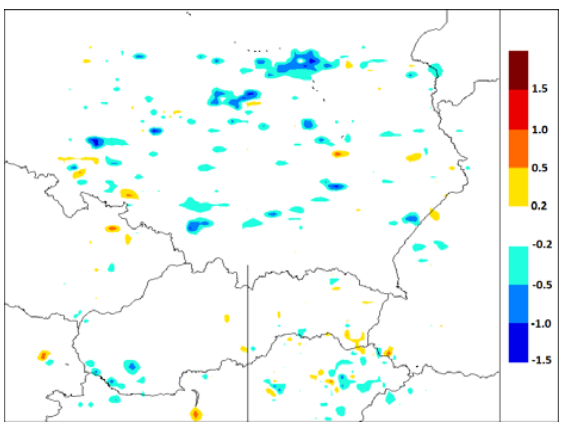

Fig. 7. Temperature (a) and wind speed (b) anomaly calculated as the difference between urban and non-urban scenarios -3 January 2011 , 12:00 UTC.

(a) $\mathrm{NO}_{2}$ concentration anomaly $\left[\mathrm{ppb} b_{\mathrm{v}}\right]$

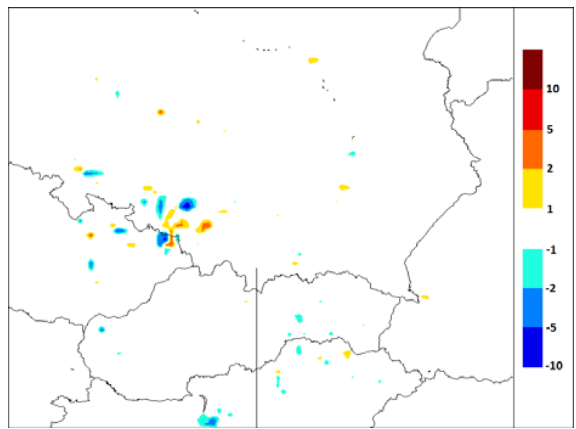

(b) CO concentration anomaly $\left[\mathrm{ppb}_{\mathrm{v}}\right]$

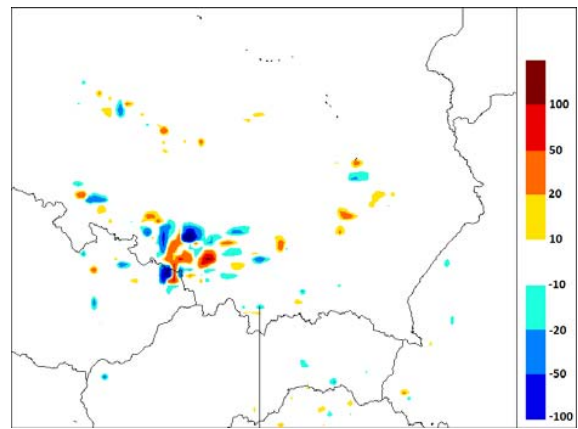

Fig. 8. $\mathrm{NO}_{2}$ (a) and $\mathrm{CO}(\mathbf{b})$ concentration anomalies calculated as the difference between urban and non-urban scenarios in the lowest model layer - 3 January 2011, 12:00 UTC.

for the Warsaw agglomeration, while in Krakow-Nowa Huta and Trzebinia the differences between scenarios are negligible.

The analysis of pollutant concentration anomalies does not provide a clear tendency. Over most of the domain the differences in $\mathrm{NO}_{2}$ concentrations are in the range of $\pm 1 \mathrm{ppb}$ (Fig. 8). Small positive anomalies $\left(\sim 2 \mathrm{ppb}_{v}\right)$ are found over Warsaw and downwind from Katowice agglomerations. However, over Katowice the difference between urban and non-urban scenario is negative and ranges up to $10 \mathrm{ppb}_{v}$. Similar pattern is observed in the case of CO concentration fields. The spatial pattern of anomalies seems to be related to the location of emission sources in the cities or nearby, rather than with the built-up density and height.

Also, the analysis of the time series does not give the consistent relationship. In Poznan and Warsaw $\mathrm{NO}_{2}$ concentrations are slightly higher in the morning hours, with the TEB parameterization applied. However, for the rest of the day there is no difference between the two scenarios. In Wroclaw $\mathrm{NO}_{2}$ concentrations calculated with the urban scenario was slightly lower as compared to the reference run results. In general, the differences for all analyzed grid cells were very small. For $\mathrm{O}_{3}$ concentrations the variability of the anomalies strictly related to $\mathrm{NO}_{2}$ changes and showed an opposite pattern. For $\mathrm{CO}$ for most of the stations there was no difference between scenarios. For Kedzierzyn-Kozle, Krakow and Trzebinia locations CO concentration levels calculated with the urban scenario are lower than the reference run during the first half of the day and higher in the evening and night.

\subsubsection{Model evaluation}

On 3 January 2011 meteorological measurements were available from 12 stations for the temperature, 9 stations for the wind speed and 3 stations for the relative humidity.

Air temperature measured at all stations was $-5^{\circ} \mathrm{C}$ and did not show the diurnal pattern. The model tends to underestimate temperature at most of the stations (average bias is $-2{ }^{\circ} \mathrm{C}$ ). The only exception is Wroclaw, where the temperature was overestimated for most of the day. During nighttime in Poznan and Kielce (Fig. 9) the model predicted a significant temperature decrease which was not observed. At other stations the average tendency of temperature changes is reproduced correctly. The range of the variability of the 

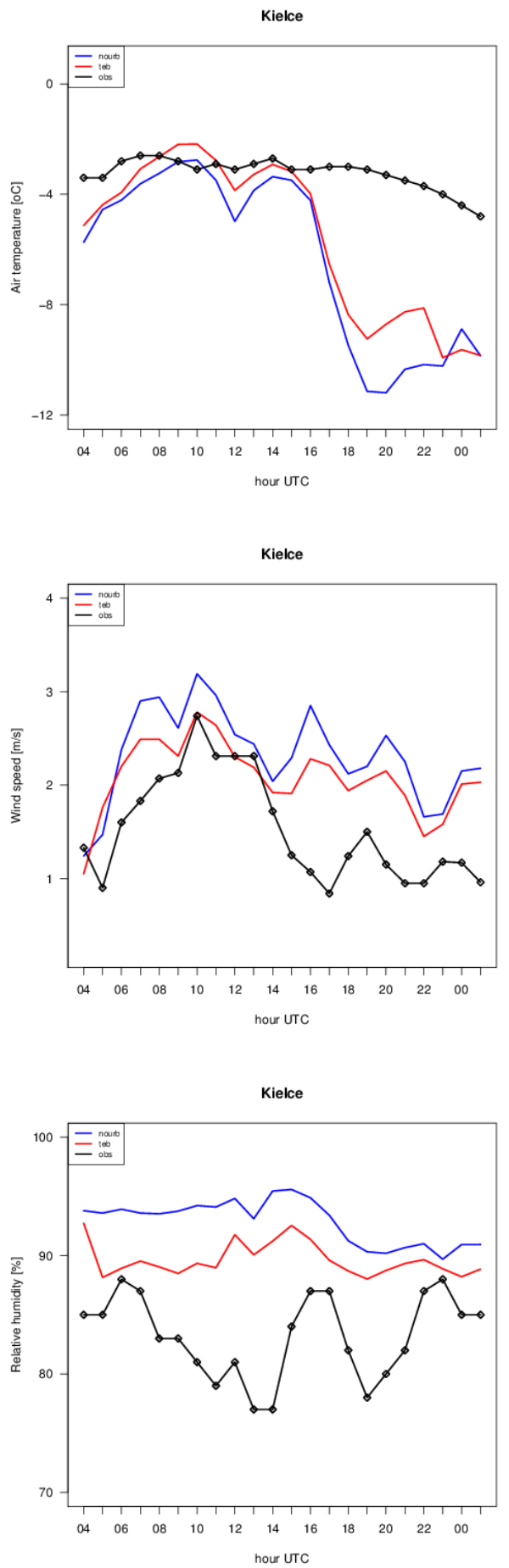

Fig. 9. Comparison of modelled meteorological parameters with observations from Kielce station for 3 January 2011 (red line - urban scenario, blue line - non-urban scenario, black line - observations).

wind speed was reproduced correctly at most stations (average MBE $=0.65 \mathrm{~m} \mathrm{~s}^{-1}$ for urban scenario). At some stations (Warsaw-Krucza, Warsaw-Targowek, Opole) the model systematically underestimated wind speed by about $1-2 \mathrm{~m} \mathrm{~s}^{-1}$.
At two stations (Kielce and Warsaw-Ursynow) modelled relative humidity agrees well with the observed values, which was around $85 \%$. At the station Warsaw-Krucza reported observations are at the level of $50 \%$. The model overestimated at this location; however, taking into consideration the fact that the relative humidity measured on Warsaw-Ursynow was much higher, the quality of this measurement series is questionable.

Comparison with $\mathrm{NO}_{2}$ observations at 11 stations shows very good agreement with measurements for most of the stations (Fig. 10). The model underestimated only the $\mathrm{NO}_{2}$ levels at traffic station Warsaw-Al. Niepodleglosci. Ozone measurements were available from 3 stations for that day only. At all sites (Kielce, Warsaw-Krucza, Warsaw-Targowek) the model underestimated ozone levels by $\sim 25 \mu \mathrm{g} \mathrm{m}^{-3}$. Modelled CO concentrations were compared with measurements from 7 monitoring stations. For stations in Poznan and Warsaw-Targowek the model reproduced correctly observed CO levels (Fig. 11), while for other stations the model underestimated by $\sim 135 \mu \mathrm{g} \mathrm{m}^{-3}$.

\subsection{March 2011}

\subsubsection{Meteorological situation}

On 29 March 2011 a weak high pressure region was present over Central Europe. The wind pattern was governed by a low trough extending over Scandinavia. The inflow of air masses was from western and north-western directions and the average wind speed was in the range of $2-4 \mathrm{~m} \mathrm{~s}^{-1}$. The wind speed increased during the daytime and decreased in the evening. The "mostly clear" or "partly cloudy" sky cover dominated over Poland, which resulted in relatively rapid increase of the temperature during the daytime. During night time clear sky conditions resulted in rapid temperature decrease after sunset.

\subsubsection{Sensitivity study}

In this case the model generated the UHI effect over the biggest cities in the north-western part of the domain. The temperature anomalies for Warsaw, Poznan, Lodz and Wroclaw over city centre reached $10^{\circ} \mathrm{C}$. In the south-eastern part of the domain a very weak UHI is present. The apparent difference between these regions could be due to the assumed urban land cover or meteorological conditions for that day.

Analysis of time series confirms that for grid cells corresponding to Kielce, Kedzierzyn-Kozle, Opole, Wroclaw, Krakow and Trzebinia the impact of urban parameterization on the modelled temperature is very small or negligible. The temperature difference between urban and non-urban scenarios is present in Poznan and Warsaw (Fig. 12a). Differences between urban and non-urban scenarios are noticeable during early morning and evening/nighttime. 
Differences in modelled average wind speed between the analyzed scenarios were relatively small and are in the range of $\pm 0.5 \mathrm{~m} \mathrm{~s}^{-1}$. The pattern of anomalies is only partly related to city locations. Over the centres of Warsaw, Lodz and Poznan there is a local increase of the average wind speed. However, over the surrounding suburbs, average wind speed was lower as compared to the reference run (Fig. 12b). The analysis of wind speed diurnal variability for both scenarios is consistent for the other two cases. For most locations the average wind speed calculated with the "urban" scenario is slightly lower than obtained in the reference run. The differences are largest during morning hours, while in the afternoon and nighttime the urban effect is very small. For two stations in Poznan and two stations in Warsaw centre (Krucza and Al. Niepoleglosci), the wind speed from the urban scenario is higher than in the reference run, which was also noted in the spatial distribution of the anomalies.

Specific humidity anomalies were negative over the entire domain and the spatial pattern was related to the location of urban areas. Time series analysis for the relative humidity showed that model results obtained with urban parameterization led to the reduction of this parameter in Poznan and in two stations in Warsaw centre the average difference between the two model scenarios is about $10 \%$, while for other stations the effect of humidity reduction is much smaller $(\sim 2 \%)$.

Anomalies of air pollutant concentrations are negative over Warsaw, Lodz, Wroclaw, Katowice and Krakow. $\mathrm{NO}_{2}$ concentration decreased by $\sim 5 \mathrm{ppb}_{v}$ and $\mathrm{CO}$ by $\sim 50 \mathrm{ppb}_{v}$ (Fig. 13). $\mathrm{O}_{3}$ anomalies are closely related to the $\mathrm{NO}_{2}$ pattern in the regions where $\mathrm{NO}_{2}$ decreased the ozone concentrations were higher by $\sim 2-5 \mathrm{ppb}_{v}$.

The time series analysis for $\mathrm{NO}_{2}$ confirms the decrease of $\mathrm{NO}_{2}$ concentrations calculated for the urban scenario. However, this effect is very small. The $\mathrm{O}_{3}$ concentrations slightly increased during the daytime and decreased during nighttime. For $\mathrm{CO}$ concentrations the differences were negligible.

\subsubsection{Model evaluation}

On 29 March 2011 meteorological measurements were available from 12 stations for the temperature, 9 stations for the wind speed and 8 stations for the relative humidity.

The observed temperature shows diurnal cycle due to radiation. The model reproduced this pattern correctly, although for most stations the maximum daily temperature was underestimated. The modelled temperature was higher than observations only at Wroclaw-Bartnicza site. For some stations a phase shift in the morning temperature increase between modelled and observed series is noted (Fig. 14a). In most stations the morning temperature increase in the model results is more rapid than observed. Modelled wind speed reflects the observed variability pattern (increase around noon and decrease in the evening). For Poznan and Wroclaw stations the agreement between model and measurements is very good.

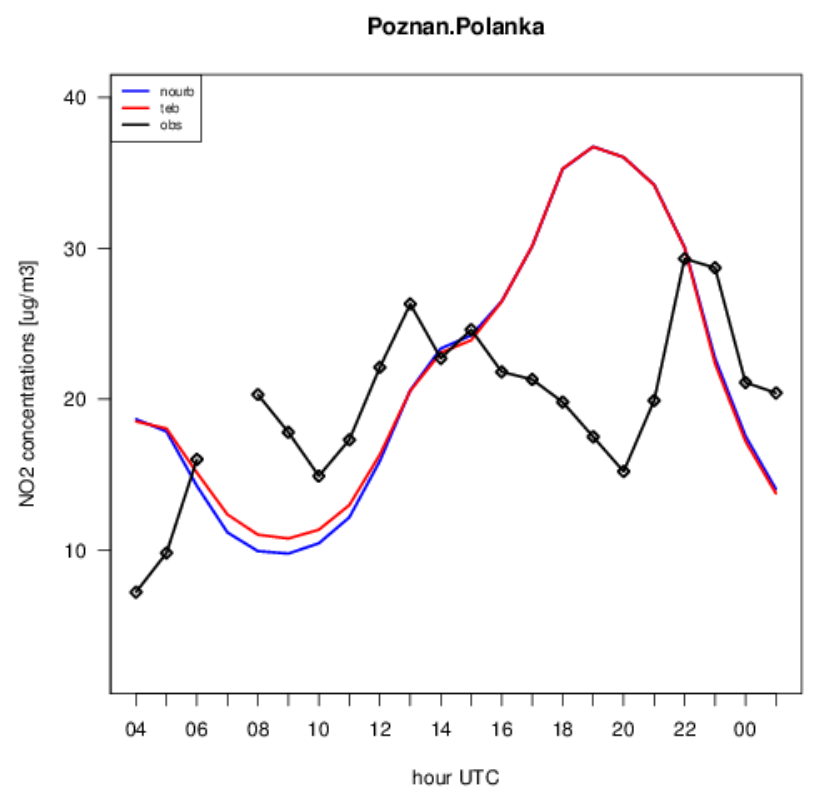

Fig. 10. Comparison of modelled $\mathrm{NO}_{2}$ concentrations with observations from station Poznan-Polanka for 3 January 2011 (red line urban scenario, blue line - non-urban scenario, blak line - observations).

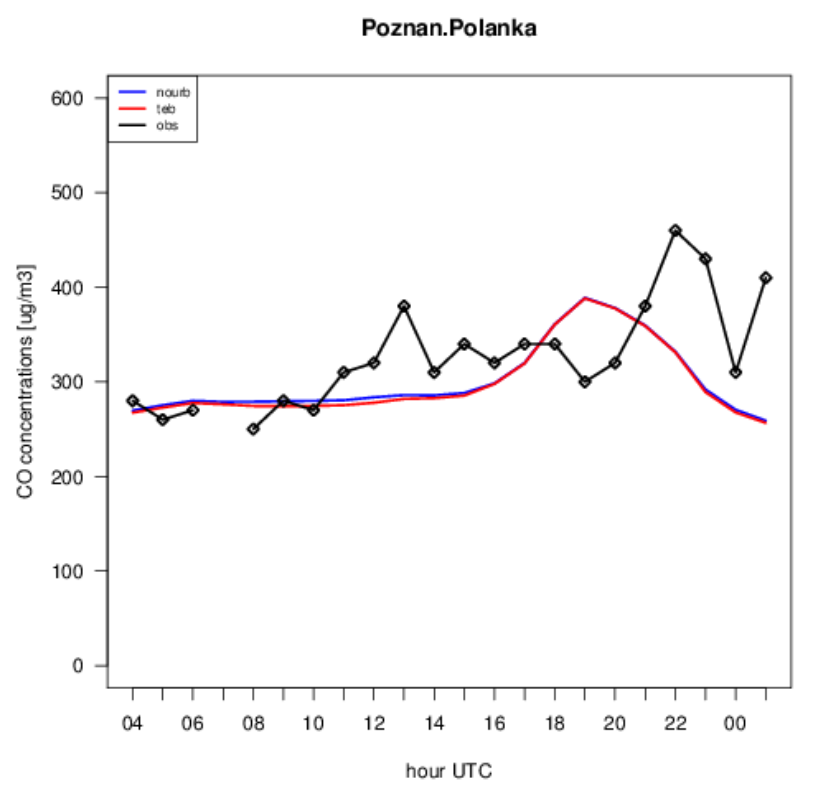

Fig. 11. Comparison of modelled CO concentrations with observations from station Poznan-Polanka for 3 January 2011 (red line urban scenario, blue line - non-urban scenario, black line - observations).

At other stations the model tends to overestimate the wind speed up to $1.5 \mathrm{~m} \mathrm{~s}^{-1}$ on average.

Comparison of modelled relative humidity with measurements shows that the diurnal variation was reproduced 
(a) Temperature anomaly $\left[{ }^{\circ} \mathrm{C}\right]$

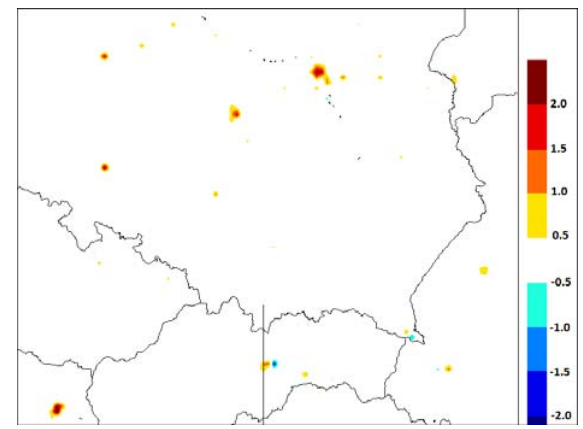

(b) Wind speed anomaly $[\mathrm{m} / \mathrm{s}]$

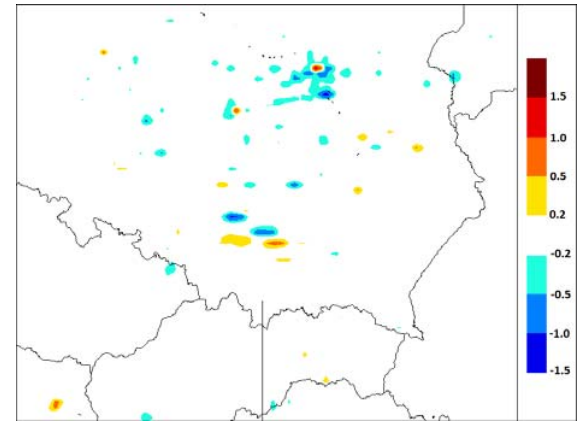

Fig. 12. Temperature (a) and wind speed (b) anomaly calculated as the difference between urban and non-urban scenarios - 29 March 2011 , 18:00 UTC.

(a) $\mathrm{NO}_{2}$ concentration anomaly $\left[\mathrm{ppb}_{\mathrm{v}}\right]$

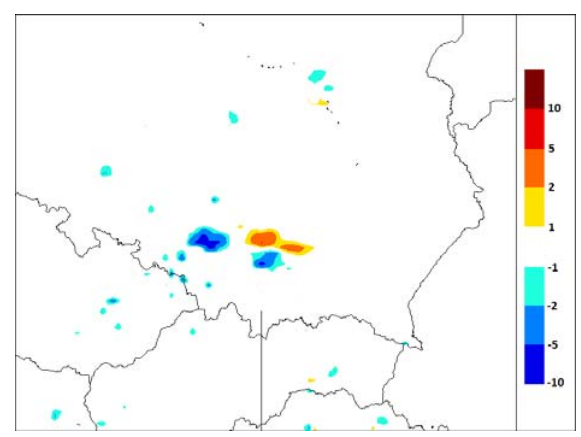

(b) CO concentration anomaly $\left[\mathrm{ppb}_{\mathrm{v}}\right]$

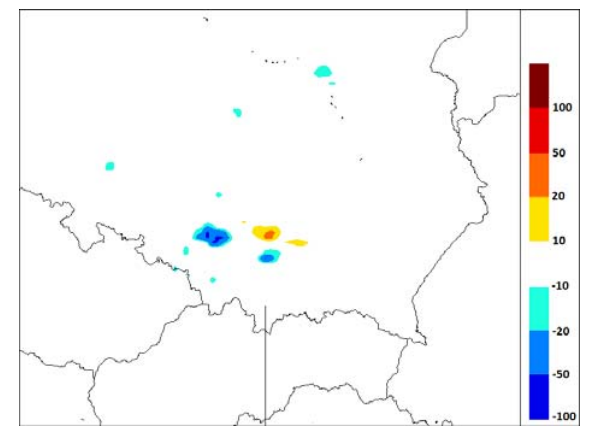

Fig. 13. $\mathrm{NO}_{2}$ (a) and $\mathrm{CO}$ (b) concentration anomalies calculated as a difference between urban and non-urban scenarios in the lowest model layer - 29 March 2011, 18:00 UTC.

correctly. However, for most of the stations the model underestimated humidity during nighttime and overestimated the daily minimum. In Warsaw modelled relative humidity is slightly overestimated. The differences between modelled and observed relative humidity are influenced not only by the difference in moisture content but also by differences in the temperature.

For 29 March $\mathrm{NO}_{2}$ measurements were available from 13 air quality monitoring stations. Observations at all sites show two peaks that relate to traffic intensity, i.e. mobile emissions. For Poznan, Wroclaw-Karlowice and stations in Warsaw the diurnal cycle was not reproduced and modelled concentrations during traffic rush hours are underestimated. A very good agreement was found in Wroclaw-Bartnicza (Fig. 15) and Krakow-NowaHuta. In Trzebinia the model overestimated $\mathrm{NO}_{2}$ levels. Ozone observations from 7 stations show diurnal cycle which was reproduced in the modelled ozone fields. In most cases the diurnal maximum is slightly underestimated, while concentrations during morning and evening hours are overestimated (Fig. 16). Measurements of CO concentrations from 7 stations show two peaks, first in early morning and the accumulation during nighttime. Although the modelled concentration levels agree well with observations during the daytime, highest concentrations were not reproduced.

\subsection{Statistical evaluation - forecast performance}

Although the length of the simulations does not allow for statistically significant error measure analysis for each station, an attempt has been made to compare results from two scenarios in terms of forecast skill score. Three measures were calculated: mean bias error (MBE); absolute gross error (MAGE); and Pearson correlation coefficient.

For each of the modelled days, the average error measures taking into account all available stations were calculated (Table 3). Temperature changes in urban scenario resulted in better model performance. The MBE was reduced by half, and MAGE was lower, especially for the 1 January and 29 March cases. MBE values indicate that the model tends to underestimate the temperature. MBE for wind speed for all simulated days indicate that the model tends to overestimate this parameter. Results obtained from the urban scenario show reduction of MBE and MAGE. However, 
Table 3. Statistical error measure averaged over stations.

\begin{tabular}{|c|c|c|c|c|c|c|c|}
\hline \multicolumn{2}{|c|}{ Error statistics Parameter } & \multicolumn{2}{|c|}{ MBE } & \multicolumn{2}{|c|}{ MAGE } & \multicolumn{2}{|c|}{ Correlation } \\
\hline & Non-urban & Urban & Non-urban & Urban & Non-urban & Urban & \\
\hline \multirow[t]{3}{*}{$T\left[{ }^{\circ} \mathrm{C}\right]$} & 2010-11-06 & -0.13 & 0.049 & 1.57 & 1.57 & 0.79 & 0.78 \\
\hline & 2011-01-03 & -2.03 & -1.05 & 2.98 & 2.16 & 0.92 & 0.949 \\
\hline & 2011-03-29 & -1.87 & -0.94 & 2.76 & 2.19 & 0.91 & 0.92 \\
\hline \multirow[t]{3}{*}{ Wind $\left[\mathrm{m} \mathrm{s}^{-1}\right]$} & 2010-11-06 & 1.90 & 1.23 & 2.01 & 1.55 & 0.42 & 0.37 \\
\hline & 2011-01-03 & 1.25 & 0.90 & 1.43 & 1.14 & 0.47 & 0.44 \\
\hline & 2011-03-29 & 1.17 & 0.90 & 1.31 & 1.10 & 0.55 & 0.53 \\
\hline \multirow[t]{3}{*}{ RH [\%] } & 2010-11-06 & -1.39 & -4.65 & 9.87 & 10.48 & 0.51 & 0.49 \\
\hline & 2011-01-03 & 0.10 & -1.56 & 13.16 & 10.83 & 0.11 & 0.42 \\
\hline & 2011-03-29 & 3.87 & 0.54 & 16.08 & 13.66 & 0.39 & 0.58 \\
\hline \multirow[t]{3}{*}{$\mathrm{NO}_{2}\left[\mu \mathrm{g} \mathrm{m}^{-3}\right]$} & 2010-11-06 & -8.28 & -10.32 & 11.85 & 12.23 & 0.21 & 0.23 \\
\hline & 2011-01-03 & -6.26 & -7.32 & 11.76 & 11.86 & 0.37 & 0.39 \\
\hline & 2011-03-29 & -10.33 & -11.52 & 19.02 & 19.16 & 0.20 & 0.20 \\
\hline \multirow[t]{3}{*}{$\mathrm{O}_{3}\left[\mu \mathrm{g} \mathrm{m}^{-3}\right]$} & 2010-11-06 & 2.20 & 5.210 & 15.07 & 14.70 & -0.07 & -0.061 \\
\hline & 2011-01-03 & -8.41 & -6.37 & 20.01 & 19.68 & -0.03 & -0.004 \\
\hline & 2011-03-29 & -0.69 & 0.64 & 21.41 & 21.36 & 0.42 & 0.41 \\
\hline \multirow[t]{3}{*}{$\mathrm{CO}\left[\mu \mathrm{g} \mathrm{m}^{-3}\right]$} & 2010-11-06 & -1323.8 & -97.18 & 1323.75 & 145.92 & -0.11 & 0.34 \\
\hline & 2011-01-03 & -727.02 & -147.35 & 767.73 & 209.46 & 0.35 & 0.29 \\
\hline & 2011-03-29 & -552.65 & -179.05 & 625.98 & 263.68 & 0.29 & 0.24 \\
\hline
\end{tabular}

the correlation coefficient was not improved. Introduction of the TEB parameterization resulted in small improvement of MAGE and correlation coefficient on 1 January and 29 March calculated for the relative humidity. Differences between error measures for urban and non-urban scenarios are very small for the $\mathrm{NO}_{2}$ and $\mathrm{O}_{3}$ concentrations. Model performance was better in the reference run for $\mathrm{NO}_{2}$, while $\mathrm{O}_{3}$ concentrations slightly improved on 1 January and 29 March. There was a significant improvement of MBE and MAGE calculated $\mathrm{CO}$ for all three cases.

Also, error measures were combined for each station taking into account results obtained from three cases. For the temperature at most of the stations (Warsaw, Krakow, Trzebinia) results obtained for 6 November and 3 January are underestimated, and standard deviation is relatively small (for both urban and non-urban scenarios). For WroclawBartnicza and Opole stations the model tends to overestimate the near-surface temperature (Fig. 17).

The modelled wind speed is overestimated, especially on 6 November. The application of urban parameterization reduces the bias. At Wroclaw-Bartnicza station the agreement between modelled and observed wind speed is good (Fig. 18).

$\mathrm{NO}_{2}$ concentrations are close to the observations on 6 November and 3 January. Largest differences are noted on 29 March. In general, $\mathrm{NO}_{2}$ concentrations are underestimated. However, in Krakow-Nowa Huta and Trzebinia the model tends to overestimate $\mathrm{NO}_{2}$ levels. For ozone the pattern is similar for all stations and seems to be governed by meteorological situation. Relatively good agreement (in terms of bias) was for 6 November; for 3 January ozone concentrations are underestimated, while for 29 March lower concentrations (nighttime) are overestimated and higher (daytime peaks) underestimated (Fig. 19). CO concentrations are, in general, underestimated by the model. Worst performance was found for 29 March, when observations showed accumulation of $\mathrm{CO}$ during nighttime.

\section{Conclusions}

The sensitivity study with GEM-AQ model in a high resolution configuration was undertaken to assess the impact of the TEB urban parameterization on a short-term meteorological and air quality forecast. At a resolution of a few kilometres over a city the general features of the urban boundary layer are reproduced, but surface description is not sufficient to capture variability of atmospheric processes observed in street canyons or in locations surrounded by buildings. It is not evident whether use of the urban parameterization will improve the model predictions and if the evaluation against observations from urban stations is reliable at that resolution.

Although in the case of the presented analysis the urban structure representation was simplified, the model response was correct in terms of magnitude of the anomalies for the selected meteorological conditions. All three case studies were selected for cold periods of the year, and hence, modification 

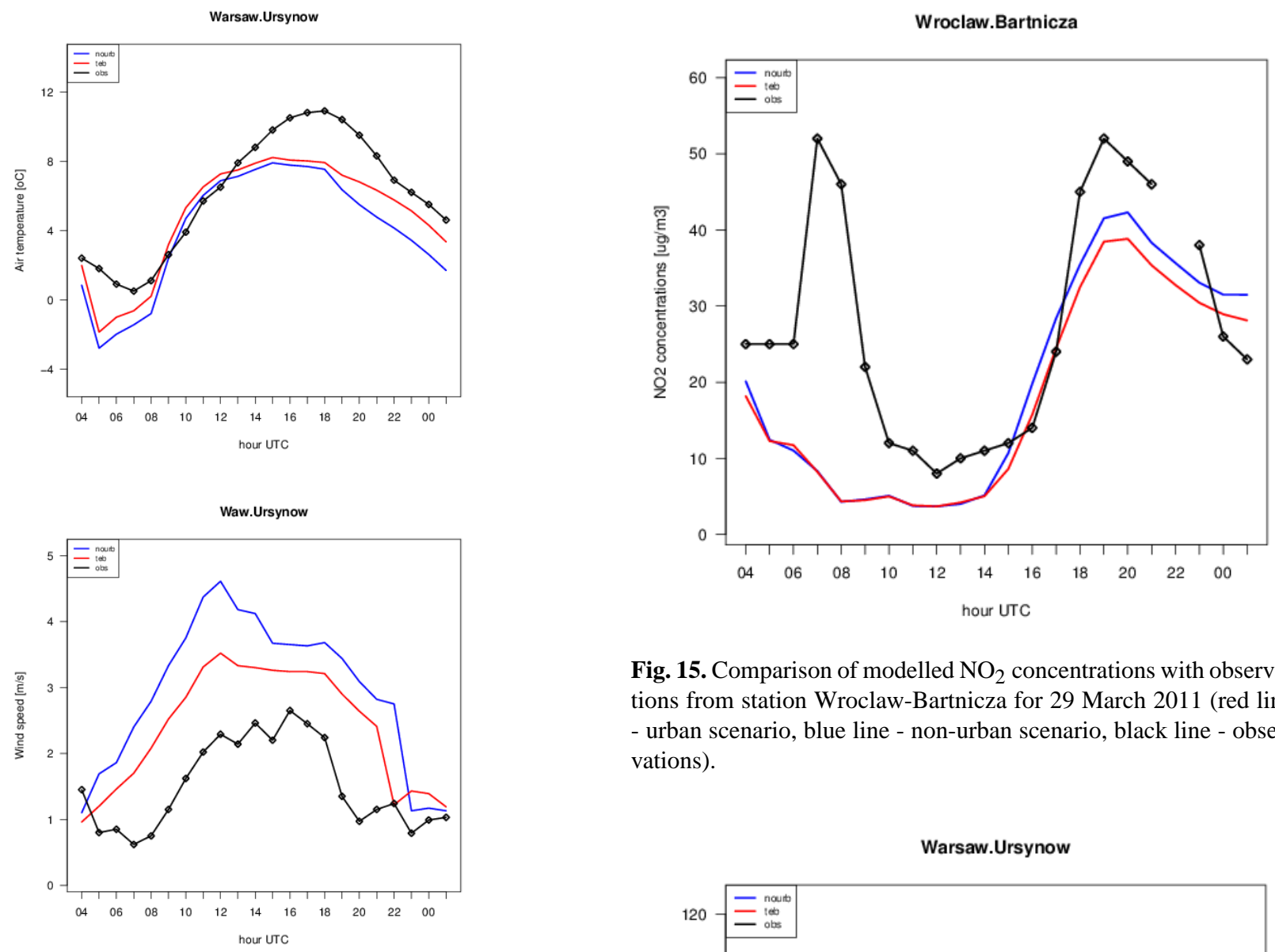

Fig. 15. Comparison of modelled $\mathrm{NO}_{2}$ concentrations with observations from station Wroclaw-Bartnicza for 29 March 2011 (red line - urban scenario, blue line - non-urban scenario, black line - observations).

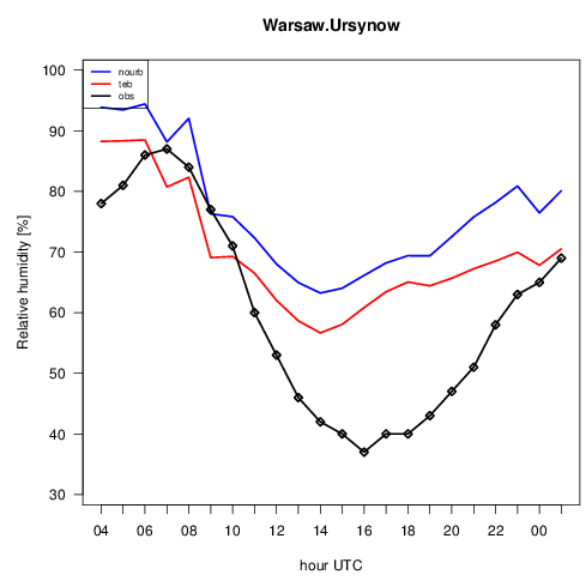

Fig. 14. Comparison of modelled meteorological parameters with observations from Warsaw-Ursynow station for 29 March 2011 (red line - urban scenario, blue line - non-urban scenario, black line observations).

of the radiation budget due to differences in albedo and emissivity of the urban surface was minimized. The factors that played major roles in UHI evolution were the magnitude of the net anthropogenic heat flux and the regional wind speed.

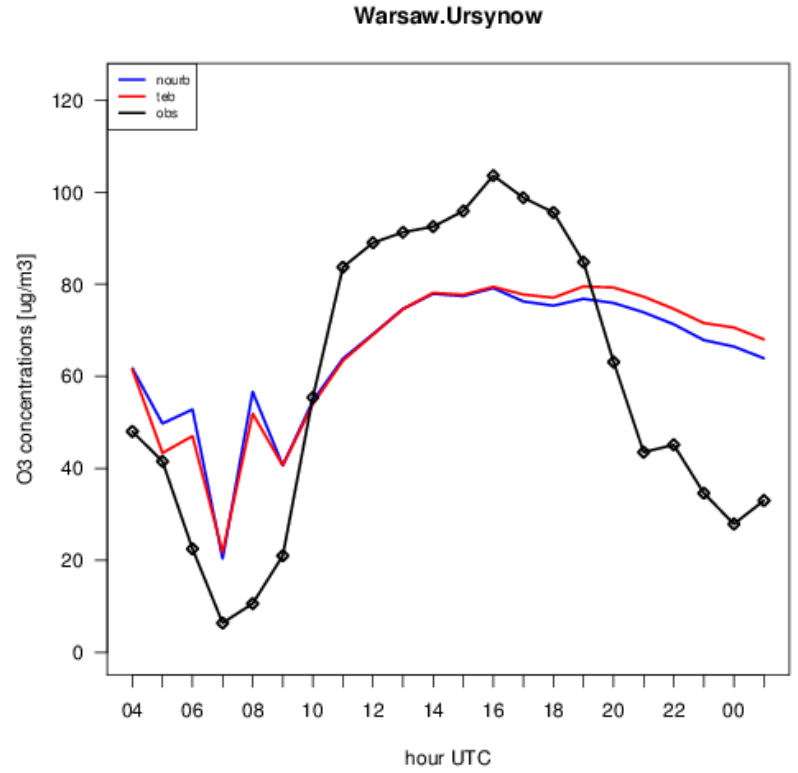

Fig. 16. Comparison of modelled $\mathrm{O}_{3}$ concentrations with observations from station Warsaw-Ursynow for 29 March 2011 (red line urban scenario, blue line - non-urban scenario, black line - observations).

To assess the response of the GEM-AQ model to the TEB parameterization differences between urban and non-urban scenarios for the meteorological parameters and air pollutant concentrations in the lowest model layer were analysed. 

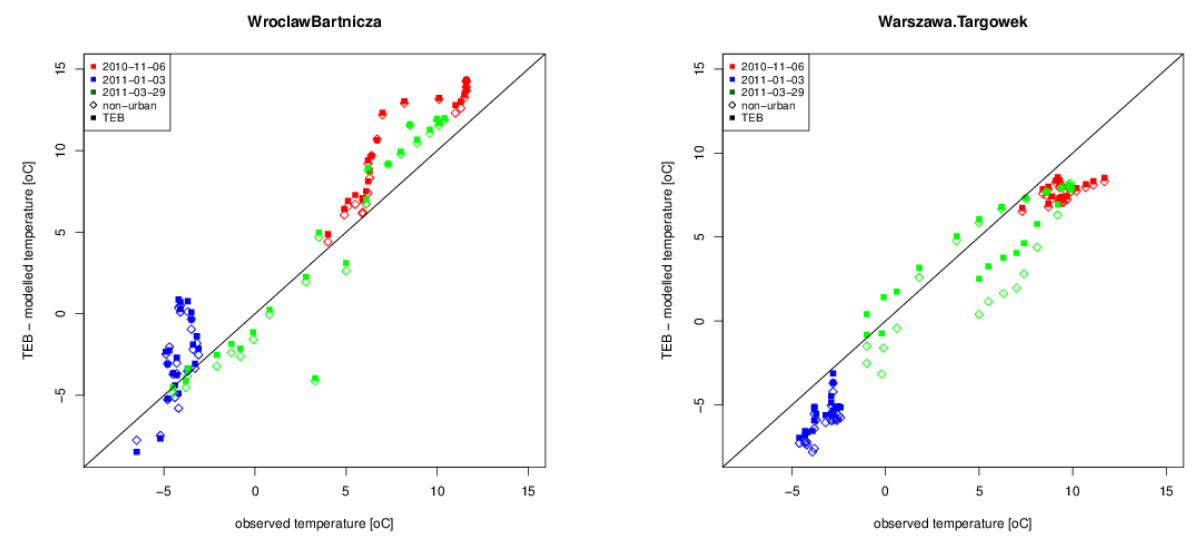

Fig. 17. Near surface temperature measured at Wroclaw-Bartnicza and Warsaw-Targowek air-quality monitoring stations and calculated with the GEM-AQ model. Full colour with the TEB parameterization and the reference case outlined colour, red: 6 November 2010; blue: 3 January 2011; green: 29 March 2011.
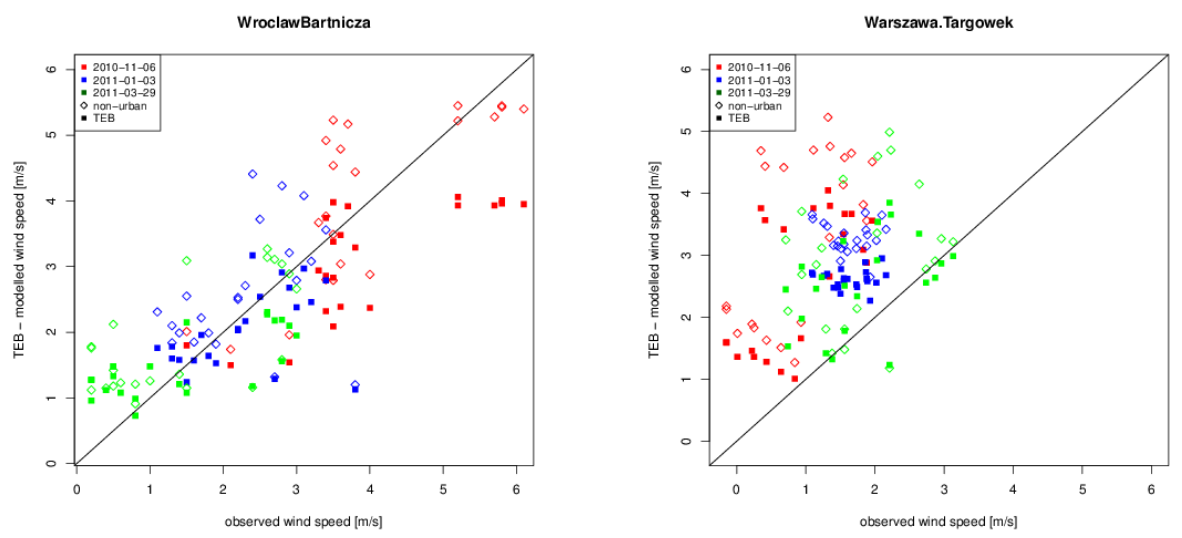

Fig. 18. Near surface wind speed measured at Wroclaw-Bartnicza and Warsaw-Targowek air-quality monitoring stations and calculated with the GEM-AQ model. Full colour with the TEB parameterization and the reference case outlined colour, red: 6 November 2010; blue: 3 January 2011; green: 29 March 2011.

- In each modelled case the spatial distribution of UHI was different and depended on the weather pattern. For the 6 November 2010 case, the wind speed was strong enough to prevent the accumulation of warmer air mass over the city. For the 3 January 2011 case, in the lowwind conditions many local UHI structures developed, especially over cities described with "city centre" and "middle suburb" built-up classes. On 29 March 2011, characterized with moderate regional wind, the UHI developed only over the largest cites.

- The average regional wind speed is reduced in the presence of urban areas. This reduction is more significant in the case of strong wind speeds (6 November 2010 case). The comparison with the measurements showed that for four stations corresponding with "city centre" land cover category the wind speed calculated with the urban scenario is higher than in the reference run. This effect was noted in all three modelled cases.
- The analysis of specific humidity anomalies and the relative humidity indicates that the use of the TEB parameterization leads to a reduction of moisture content in the air. The difference is small but systematic over the entire domain. During spring or summer this effect could be more significant due to relatively higher saturated water vapour pressure and more intensive evaporation processes.

- Concerning the primary pollutant concentrations, the impact of urban areas is most significant in regions characterized with high emissions. In most cases the anomalies of $\mathrm{NO}_{2}$ and $\mathrm{CO}$ concentrations are negative. The reduction can be explained by enhanced vertical mixing due to elevated surface temperature and modified vertical stability. In some cases the increase of concentrations is probably due to accumulation related to a reduced wind speed in weak UHI conditions. 

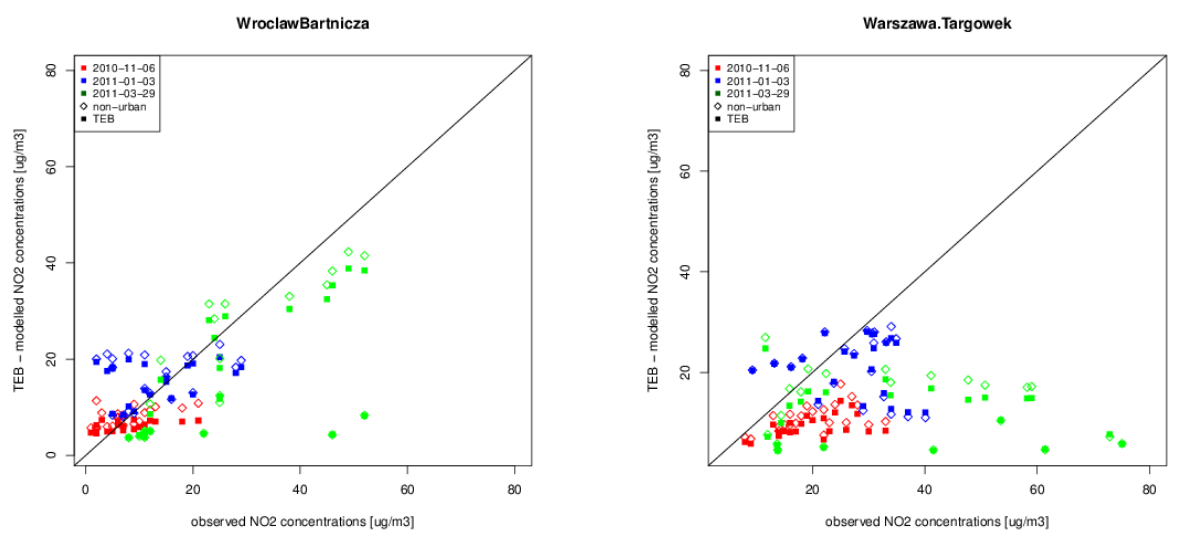

Fig. 19. Near surface $\mathrm{NO}_{2}$ concentrations measured at Wroclaw-Bartnicza and Warsaw-Targowek air-quality monitoring stations and calculated with the GEM-AQ. Full colour with the TEB parameterization and the reference case outlined colour, red: 6 November 2010; blue: 3 January 2011; green: 29 March 2011.

- The pattern of $\mathrm{O}_{3}$ concentration anomalies is closely related to the spatial variability of $\mathrm{NO}_{2}$ concentrations. The negative anomalies of $\mathrm{NO}_{2}$ correspond to the increase of ozone concentrations. During spring and summer, when photochemical processes are active, the $\mathrm{O}_{3}$ variability would probably be more complex.

- The impact of the TEB parameterization on pollutant concentrations is not constrained to urban areas, but also influences regions located downwind and near industrial area (emission sources).

The sensitivity analyses were completed with evaluation against meteorological and air quality data from selected urban background monitoring stations. The comparison of observed and modelled temperature shows that for most stations, temperature predicted with the TEB parameterization applied was more accurate in terms of statistical error measures on 3 January and 29 March, but the difference between scenarios was small. The temperature increase related to anthropogenic heat flux release and modified surface radiative properties is present in low-wind conditions and limited solar irradiance, but on 3 January the model underestimated the temperature for both scenarios. In the case of the 29 March, the TEB parameterization did not have an impact on modelled maximum temperature as compared to non-urban scenario. Also, the phase shift in the morning temperature rise requires further analysis, and indicates the need for more detailed surface fluxes analysis.

The model evaluation undertaken for the wind shows that application of the urban parameterization in most cases improves modelled results as compared to the observations taken at urban background monitoring stations. In general, the model tends to overestimate the wind speed in urban areas and the reduction of average wind speed obtained for urban scenario results in lower values of error measures.
For air pollutant concentrations there is no systematic trend in changes due to urban effects. In order to improve air quality prediction at these scales a more realistic representation of emission fluxes as well as its diurnal time profile is required.

The analyses presented above allow for summarizing the impact of urban parameterization on meteorological and air quality forecast with the GEM-AQ model:

1. Although the differences between urban and non-urban scenarios were relatively small for all analyzed meteorological and chemical parameters, these differences are well interpretable in terms of weather conditions

2. Impact of the TEB parameterization on modelled temperature and UHI evolution depends on the weather conditions during the analysed day and on the properties of the urban area

3. There is a need for a revision of the anthropogenic heat fluxes for each urban cover class and implementation of temporal profiles

4. Impact of the TEB parameterisation is most significant in the situation when solar radiation has no (or little) contribution to the surface heating (case of winter weather on 3 January or night hours on 29 March 2011)

5. Application of the TEB parameterization slightly reduces the differences between the model and measurements taken at urban stations. However, as measurements taken at urban background stations might not be representative for the results obtained in both scenarios, a significant improvement of the model performance should not be expected

6. On 29 March the modelled temperature increase in the morning occurred earlier and was stronger than 
observed, while in the afternoon modelled temperature decrease was more rapid. This requires further analysis of modelled surface fluxes variability in different stability regimes

7. Results obtained for 6 November show negligible impact of the urban parameterization. In terms of error measures, the model performance was not improved for that day. This indicates that for days characterised with dynamic changes in meteorological situation and strong wind the use of urban parameterization will not improve the modelling results

Although the outcome from this sensitivity study is promising, it does not include a sufficiently large number of simulations to give statistically significant results to give an answer concerning the benefits of using the GEM-AQ model with the TEB urban parameterization in an operational configuration for EcoForecast.eu. However, taking into account the area covered by cities in the domain and the size of major cities as compared with grid resolution, there is a need to include urban processes and improve model performance over the urban area. Additional experiments will be undertaken to better estimate the anthropogenic heat flux and to investigate the impact of "city centre" on modelled wind speed.

Acknowledgements. The authors wish to acknowledge financial support from The Malopolska Voivodeship, Poland. Also, the authors thank the anonymous reviewers for their helpful comments.

Edited by: A. Baklanov

\section{References}

Bagienski, Z.: Anthropogenic Heat Release for Urban Area, Inzynieria i Ochrona Srodowiska, 9, 61-78, 2006.

Baklanov, A., Korsholm, U., Mahura, A., Petersen, C., and Gross, A.: ENVIRO-HIRLAM: on-line coupled modelling of urban meteorology and air pollution, Adv. Sci. Res., 2, 41-46, doi:10.5194/asr-2-41-2008, 2008.

Baklanov, A.: Overview of the European project FUMAPEX, Atmos. Chem. Phys., 6, 2005-2015, doi:10.5194/acp-6-2005-2006, 2006.

Baklanov, A., Lawrence, M., Pandis, S., Mahura, A., Finardi, S., Moussiopoulos, N., Beekmann, M., Laj, P., Gomes, L., Jaffrezo, J.-L., Borbon, A., Coll, I., Gros, V., Sciare, J., Kukkonen, J., Galmarini, S., Giorgi, F., Grimmond, S., Esau, I., Stohl, A., Denby, B., Wagner, T., Butler, T., Baltensperger, U., Builtjes, P., van den Hout, D., van der Gon, H. D., Collins, B., Schluenzen, H., Kulmala, M., Zilitinkevich, S., Sokhi, R., Friedrich, R., Theloke, J., Kummer, U., Jalkinen, L., Halenka, T., Wiedensholer, A., Pyle, J., and Rossow, W. B.: MEGAPOLI: concept of multi-scale modelling of megacity impact on air quality and climate, Adv. Sci. Res., 4, 115-120, doi:10.5194/asr-4-115-2010, 2010.

Bornstein, R. D.: Observations of the urban heat island effect in New York City, J. Appl. Meteorol. 7, 575-582, 1968.
Bornstein, R. D. and Azie, I.: Urban effects on sodar derived inversion patterns in San Jose. Preprint Vol. 5th AMS Symposium on Turbulence, Atlanta, GA., 187-188, 1981.

Côté, J., Gravel, S., Méthot, A., Patoine, A., Roch, A. and Staniforth, A.: The operational CMC-MRB global environmental multiscale (GEM) model. Part I: Design considerations and formulation, Mon. Wea. Rev., 126, 1373-1395, 1998.

Cros, B., Durand, P., Frejafon, E., Kottmeier, C., Perros, P., Peuch, V., Ponche, J., Robin, D., Sad, F., Toupance, G., and Wortham, H.: The ESCOMPTE program: an overview, Atmos. Res., 69, 241-279, 2004.

Draxler, R. R.: Simulated and observed influence of the nocturnal urban heat island on the local wind field, J. Clim. Appl. Meteorol., 24, 1125-1133, 1986.

Eliasson, I. and Holmer, B.: Urban heat island circulation in GoÈteborg, Sweden, Theor. Appl. Climatol., 42, 187-196, 1990.

Fisher, B., Joffre, S., Kukkonen, J., Piringer, M., Rotach, M. W., and Schatzmann, M.: Meteorology applied to Urban Air Pollution Problems, Final Report COST 715, Luxembourg, 5 Office of Publications of European Communities, 2005.

Gauthier, P., Tanguay, M., Laroche, S., Pellerin, S., and Morneau, J.: Extension of 3D-Var to 4D-Var: Implementation of 4D-Var at the Meteorological Service of Canada, Mon. Wea. Rev., 135, 2339-2354, 2007.

Haeger-Eugensson, M. and Holmer, B.: Advection caused by the UHIC as a regulating factor on the nocturnal UHI, Int. J. Climatol., 19, 975-988, 1999.

Hamdi, R. and Schayes, G.: Validation of Martilli's urban boundary layer scheme with measurements from two midlatitude European cities, Atmos. Chem. Phys., 7, 4513-4526, doi:10.5194/acp-7-4513-2007, 2007.

Holmer, B. and Eliasson, I.: Urban-rural vapour pressure differences and their role in the development of urban heat islands, Int. J. Climatol., 19, 989-1009, 1999.

Kambezidis, H. D., Peppes, A. A., and Melas, D.: An environmental experiment over Athens urban area under sea breeze conditions, Atmos. Res., 36, 139-156, 1995.

Kaminski, J. W. and Struzewska, J.: Development and Performance of a Semi-Operational Chemical Weather Forecasting System EcoForecast.EU, EGU Assembly, 2011.

Kaminski, J. W., Neary, L., Struzewska, J., McConnell, J. C., Lupu, A., Jarosz, J., Toyota, K., Gong, S. L., Côté, J., Liu, X., Chance, K., and Richter, A.: GEM-AQ, an on-line global multiscale chemical weather modelling system: model description and evaluation of gas phase chemistry processes, Atmos. Chem. Phys., 8, 3255-3281, doi:10.5194/acp-8-3255-2008, 2008.

King, C. W. and Russell, C. A.: Temperature structure effects on pollutant distribution in the Denver metropolitan area, Joint Conference on Applications of Air Pollution Meteorology 6, 2432450, 1996.

Klysik, K.: Spatial and seasonal distribution of anthropogenic heat emissions in Lodz, Poland, Atmos. Environ., 30, 3397-3404, 1996.

Lee, D. O.: Urban-rural humidity differences in London, Int. J. Climatol., 11, 577-582, 1991.

Lemonsu, A. and Masson, V.: Simulation of a summer urban breeze over Paris, Bound.-Layer Meteorol., 104, 463-490, 2002.

Lemonsu, A., Belair, S., and Mailhot, J.: The new Canadian urban modelling system: Evaluation for two cases from the Joint 
Urban 2003 Oklahoma City experiment, Boundary Layer Meteorol., 133, 47-70, 2009.

Lemonsu, A., Bélair, S., Mailhot, J., and Leroyer, S.: Evaluation of the Town Energy Balance model under cold and snowy conditions for the Montréal Urban Snow Experiment 2005, J. Appl. Meteor. Clim., 49, 346-362, 2010.

Loveland, T. R., Reed, B. C., Brown, J. F., Ohlen, D. O., Zhu, Z., Yang, L., and Merchant, J. W.: Development of a global land cover characteristics database and IGBP DISCover from $1 \mathrm{~km}$ AVHRR data, Int. J. Remote Sensing, 21, 1303-1330, 2000.

Martilli, A., Roulet, Y. A., Junier, M., Kirchner, F., Rotach, M., and Clappier, A.: On the impact of urban surface exchange parameterisations on air quality simulations: the Athens case, Atmos. Environ. 37, 4217-4231, 2003.

Masson, V.: A physically-based scheme for the urban energy budget in atmospheric models, Bound.-Layer Meteorol., 94, 357-397, 2000.

Menut, L., Vautard, R., Flamant, C., Abonnel, C., Beekmann, M., Chazette, P., Flamant, P. H., Gombert, D., Guédalia, D., Kley, D., Lefebvre, M. P., Lossec, B., Martin, D., Mégie, G., Perros, P., Sicard, M., and Toupance, G.: Measurements and modelling of atmospheric pollution over the Paris area: an overview of the ESQUIF Project, Ann. Geophys., 18, 14671481, doi:10.1007/s00585-000-1467-y, 2000.

Oke, T. R.: Canyon geometry and the nocturnal urban heat island: Comparison of scale model and field observation, Int. J. Climatol., 1, 237-254, 1981.
Oke, T. R.: Boundary Layer Climates, 2nd edn., Routledge, 1987.

Oleson, K. W., Bonan, G. B., Feddema, J., Vertenstein, M., and Grimmond, C. S. B.: An Urban Parameterization for a Global Climate Model. Part I: Formulation and Evaluation for Two Cities, J. Appl. Meteor. Climatol., 47, 1038-1060, 2008.

Saitoh, T. S., Shimada, T., and Hoshi, H.: Modeling and simulation of the Tokyo urban heat island, Atmos. Environ., 30, 3431-3442, 1988.

Sarrata, C., Lemonsu, A., Masson, V., and Guedalia, D.: Impact of urban heat island on regional atmospheric pollution, Atmos. Environ., 40, 1743-1758, 2006.

Shahgedanova, M., Burt, T. P., and Davies, T. D.: Some aspects of the three-dimensional heat island in Moscow, Int. J. Climatol., 17, 1451-1465, 1997.

Struzewska, J. and Kaminski, J. W.: Semi-operational air quality forecast for Poland and Central Europe with the GEM-AQ model. Proceedings of the 13th International Conference on Harmonization within Atmospheric Dispersion Modelling for Regulatory Purposes, June 2010, ISBN 2-8681-5062-4., 2010.

Struzewska J. and Kaminski J. W.: Application of Model Output Statistics technique to a high resolution air quality forecast, EGU Assembly, 2011.

Struzewska, J., Kaminski J. W., and Durka, P.: Operational evaluation of a high resolution air quality forecast over Southern Poland, EGU General Assembly, 2012. 